\title{
스펙트럼영역 빛간섭단층촬영으로 경과 관찰한 용접광황반병증 Long-term Follow-up Results of Patients with Welding-arc Maculopathy Assessed Using Spectral Domain Optical Coherence Tomography
}

\author{
김지혜 ${ }^{1} \cdot$ 김범준 ${ }^{1}$ 강태신 ${ }^{1} \cdot$ 조현경 ${ }^{1,2} \cdot$ 남기엽 $^{1} \cdot$ 유지명 ${ }^{1}$ 한용섭 ${ }^{1,2}$ \\ Ji Hye Kim, MD ${ }^{1}$, Bum Jun Kim, MD ${ }^{1}$, Tae-Seen Kang, MD ${ }^{1}$, Hyun Kyung Cho, MD, PhD ${ }^{1,2}$, \\ Ki Yup Nam, MD, $\mathrm{PhD}^{1}$, Ji Myong Yoo, MD, $\mathrm{PhD}^{1}$, Yong Soep Han, MD, $\mathrm{PhD}^{1,2}$ \\ 창원경상대학교병원 안과 ${ }^{1}$, 경상대학교 의과대학 안과학교실 ${ }^{2}$ \\ Department of Ophthalmology, Gyeongsang National University Changwon Hospital ${ }^{l}$, Changwon, Korea \\ Department of Ophthalmology, Gyeongsang National University College of Medicine ${ }^{2}$, Jinju, Korea
}

\begin{abstract}
Purpose: We present four cases of welding arc maculopathy as observed using spectral-domain optical coherence tomography (SD-OCT).

Case summary: Four patients, who performed welding without wearing protective eye gear, presented to the hospital due to poor visual acuity. The mean visual acuity of the patients was 0.6 . Fundus photographs of the four patients revealed a yellowish retinal scar at the fovea. SD-OCT images of the four patients showed photoreceptor inner segment/outer segment junction (IS/OS junction) disruption and retinal pigment epithelium injury. We diagnosed the patients with welding arc maculopathy, and three of them were treated with oral steroids or antioxidants. The IS/OS junctions were restored in two patients, who had short welding arc exposures. The disrupted IS/OS junction recovered partially in one of the other two patients, who had a longer duration of exposure, and the IS/OS junction disruption remained in another patient.
\end{abstract}

Conclusions: We report four cases of welding arc maculopathy caused by welding light exposure evaluated using SD-OCT and treated with oral steroids and antioxidants.

J Korean Ophthalmol Soc 2019;60(12):1344-1351

Keywords: Maculopathy, Optical coherence tomography, Retinal pigment epithelium, Welding

빛은 다양한 영역의 전자기파로 구성되어 있어 기계적, 열적, 광화학적 효과로 조직에 영향을 준다. 특히 파장이 짧은 자외선과 청색 빛은 망막 및 망막색소상피, 맥락막에 손상을 입힌다. ${ }^{1,2}$ 고전압을 사용하는 용접기구에 의해 발생

- Received: 2019. 6. 20.

- Accepted: 2019. 11. 29.

- Revised: 2019. 8. 16.

- Address reprint requests to Yong Soep Han, MD, PhD Department of Ophthalmology, Gyeongsang National University Changwon Hospital, \#11 Samjeongja-ro,

Seongsan-gu, Changwon 51472, Korea

Tel: 82-55-214-2429, Fax: 82-55-214-1036

E-mail: medcabin@naver.com

* Conflicts of Interest: The authors have no conflicts to disclose.
하는 전자기 방사선의 조성은 빛의 구성과 상당부분 일치 한다. ${ }^{2}$ 이는 자외선, 가시광선, 적외선 등 다양한 영역의 전 자기파로 이루어져 있고 이 중 원적외선은 각막 및 렌즈에 흡수되지만 가시광선 및 자외선, 근적외선은 각막 및 렌즈 를 투과하여 망막층까지 도달한다. ${ }^{3,4}$

용접기술은 피복 금속 아크 용접부터 고온 가스 텅스텐 아크 용접, 가스 금속 아크 용접까지 수년에 걸쳐 발전되었 다. 최근 대기 중에 플라즈마 생성이 가능하게 되어 이에 대한 다양한 연구가 진행되었고 용접기술에도 접목되어 플 라즈마 아크 용접이 개발되었다. 플라즈마 아크 용접은 열 에너지의 집중도가 높아 용접시간을 단축시킬 수 있어 현 재 주로 사용되는 용접기술이다. 그러나 이 방법은 섭씨 
$10,000-30,000^{\circ}$ 의 고온을 발생시켜 많은 전자기 방사선을 방출시킴으로 다른 용접기술에 비해 망막 손상을 더 많이 유발하는 것으로 알려져 있다. ${ }^{2}$

용접광에 의한 망막 손상은 1902년 Terrien에 의해 처음 보고되었다. ${ }^{5}$ 국내에서는 Choi et $\mathrm{al}^{2}$ 이 시간영역 빛간섭단층 촬영(time domain optical coherence tomography, TD-OCT)
에서 이상 소견이 없고 시야검사에서 중심 암점을 보였던 용접광황반병증 1 예를 보고하였으나, 스펙트럼영역 빛간섭 단층촬영을 이용하여 진단하고 관찰한 용접광황반병증은 아직까지 보고된 바 없다. 이에 저자들은 스펙트럼영역 빛 간섭단층촬영으로 추적 관찰한 플라즈마 아크 용접 이후 발 생한 용접광황반병증 4예를 문헌 고찰과 함께 보고하고자 한다.
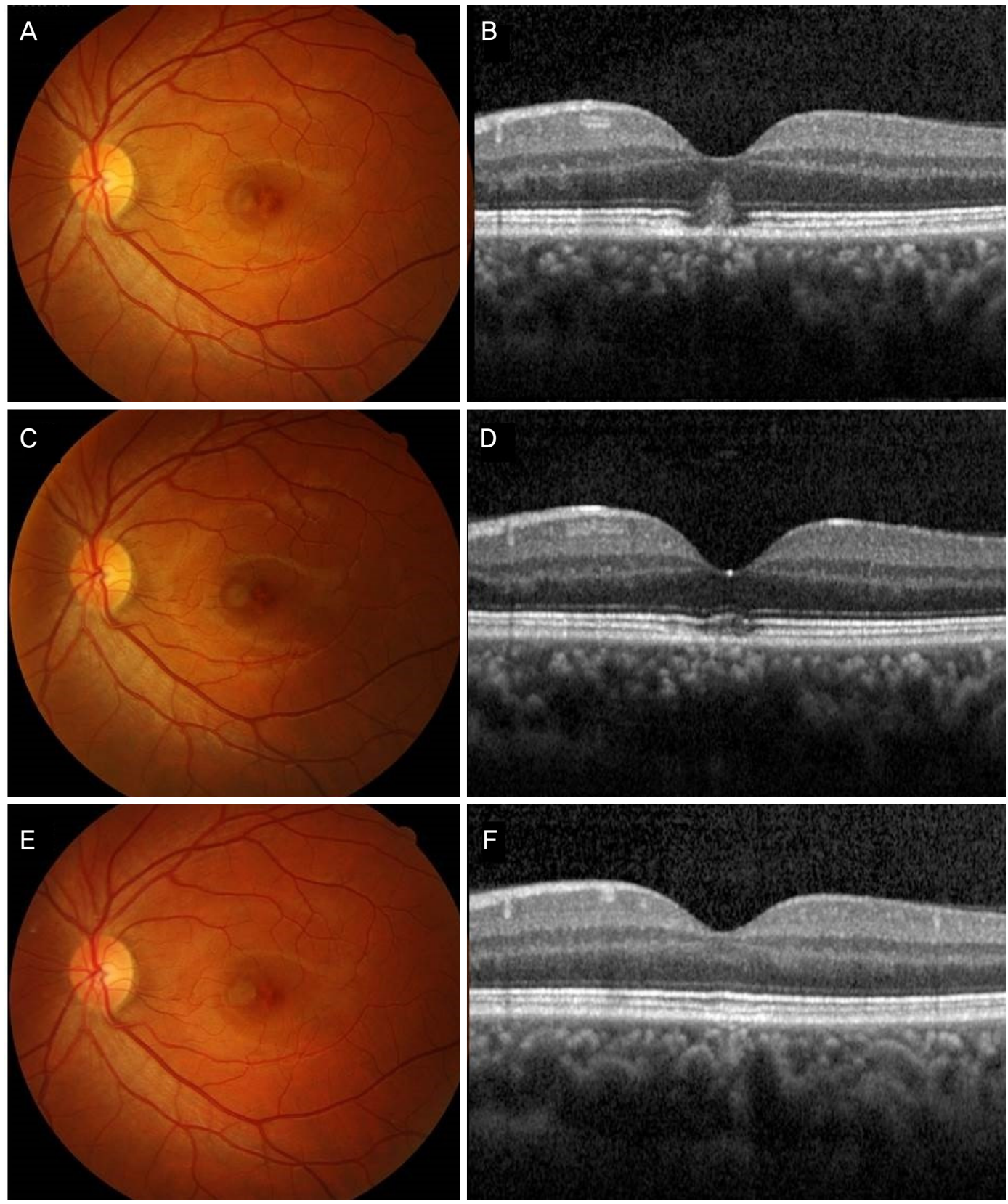

Figure 1. (Patient 1) Fundus photograph (A) and SD-OCT image obtained (B) at the first ophthalmic examination showing a yellowish retinal scar in the fovea and IS/OS junction disruption, hyperreflective band in the outer nuclear layer and RPE injury in the left eye. Fundus photograph (C) and SD-OCT image (D) after 1 month of treatment showing IS/OS junction restoration, but the retinal scar at the fovea and RPE injury persisted in the left eye. Fundus photograph (E) and SD-OCT image (F) after 1 year of treatment showing complete restoration of the IS/OS junction. SD-OCT = spectral domain optical coherence tomography; IS/OS junction = photoreceptor inner segment/outer segment junction; RPE = retinal pigmented epithelium. 


\section{증례보고}

증례 1

기저질환이 없는 39 세 남자 환자가 약 2주 전부터 특별 한 외상 없이 발생한 좌안의 시력저하와 시야에 물방울 맺 힌듯한 증상을 호소하며 내원하였다. 환자는 2 개월 전부터 불규칙하게 보호장구를 착용한 채로 용접 및 도장작업을 시행하였다. 내원 당시 환자의 최대교정시력은 우안 1.0 , 좌안 0.8 로 측정되었고 골드만압평안압계로 측정한 안압은 우안 $15 \mathrm{mmHg}$, 좌안 $14 \mathrm{mmHg}$ 였다. 세극등현미경검사에 서 전안부는 정상이었고 안저검사에서 좌안의 망막중심오 목에 황색의 반흔이 관찰되었으며(Fig. 1A) 스펙트럼영역 빛간섭단층촬영에서 좌안 빛수용체내외절경계부의 결손과 망막색소상피부터 외핵층에 걸친 고반사도의 음영 및 망막 색소상피의 손상이 관찰되었다(Fig. 1B). 환자의 병력과 안 저검사 및 스펙트럼영역 빛간섭단층촬영검사 결과를 바탕
으로 용접광황반병증으로 진단하였고 경구 prednisolone (Solondo ${ }^{\circledR}$, Yuhanyanghaeng, Seoul, Korea) $30 \mathrm{mg}$, 항산화 제(Entelon ${ }^{\circledR}$, Hanlim, Seoul, Korea) $150 \mathrm{mg}$ 및 라디칼 제 거제(Ocuvite ${ }^{\circledR}$, Bausch + Lomb South Asia Inc., Seoul, Korea) $1 \mathrm{Tab}$ 을 처방하였다. 3일 뒤 경구 prednisolone은 $20 \mathrm{mg}$ 으로 감량하였으며 이후 2주에 걸쳐 점차 감량하였 고 항산화제와 라디칼 제거제는 유지하였다. 치료 1 개월째 좌안의 최대교정시력은 0.9 였으며 안저검사에서 좌안 망막 중심오목의 황색 반흔의 크기는 감소하였고(Fig. 1C) 스펙 트럼영역 빛간섭단층촬영에서 좌안 빛수용체내외절경계부 는 점차 회복되는 모습이 관찰되었다(Fig. 1D). 치료 6개월 후 좌안의 최대교정시력은 1.0 으로 호전되었으며 스펙트럼 영역 빛간섭단층촬영에서 좌안 빛수용체내외절경계부는 회복되었고 외핵층에서 보이던 고반사도의 음영은 관찰되 지 않았다. 이후 2 년간 재발이나 악화 소견은 관찰되지 않 았다(Fig. 1E, F).
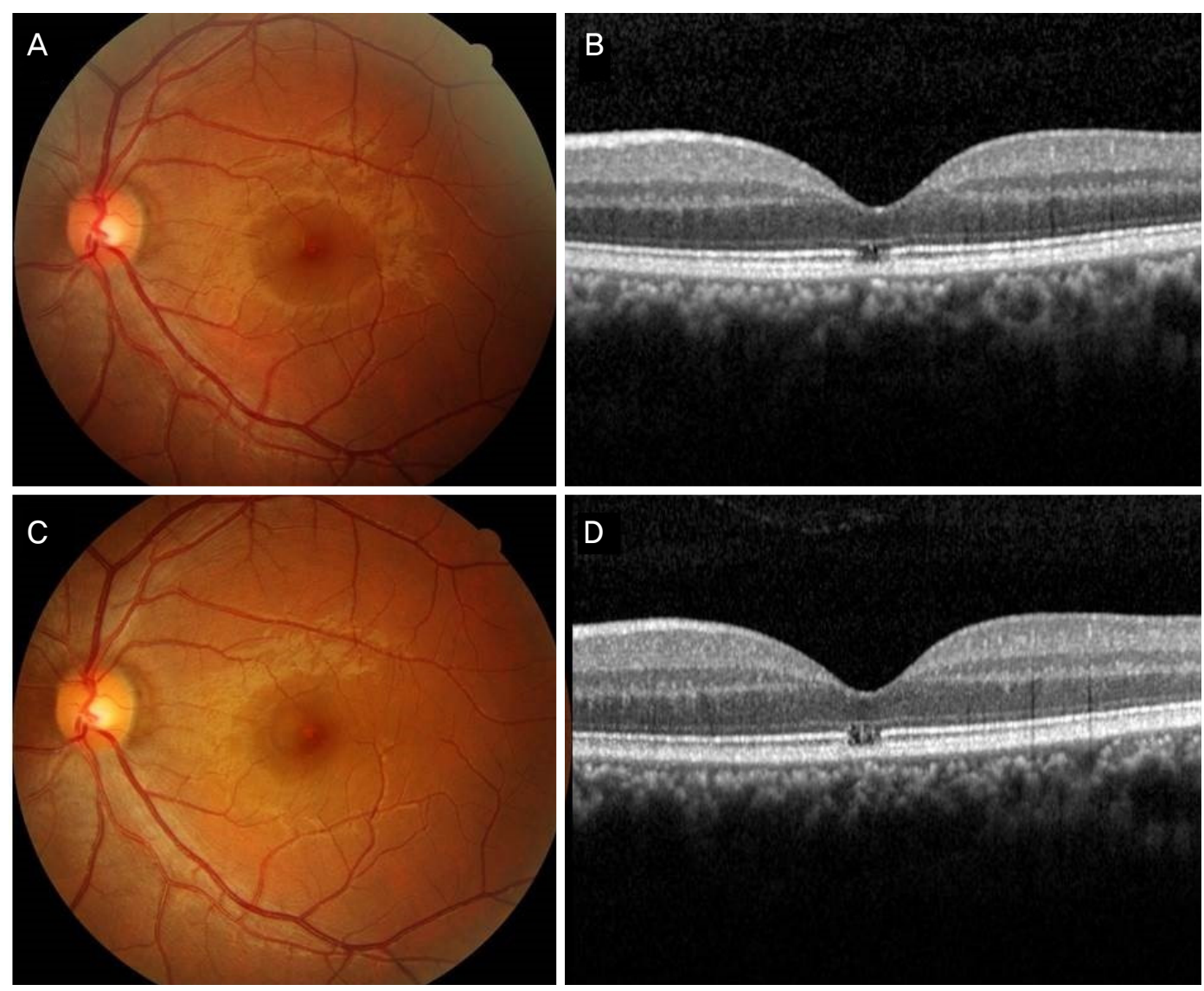

Figure 2. (Patient 2) Fundus photograph (A) and SD-OCT image (B) at the first ophthalmic examination showing yellowish retinal scar in the fovea and IS/OS junction disruption and RPE injury in the left eye. Fundus photograph (C) and SD-OCT image (D) after 1 year of treatment showing persistent IS/OS junction disruption, retinal scar in the fovea, and RPE injury. SD-OCT = spectral domain optical coherence tomography; IS/OS junction = photoreceptor inner segment/outer segment junction; RPE = retinal pigmented epithelium. 
증례 2

기저질환이 없는 32 세 남자 환자가 약 6 개월 전부터 발 생한 좌안의 시력저하를 주소로 내원하였다. 환자는 외상 의 과거력은 없었고 7 개월 전부터 보호장구의 착용 없이 용접작업을 시행하였다. 내원 당시 환자의 최대교정시력은 우안 1.0 , 좌안 0.5 로 측정되었고 골드만압평안압계로 측정 한 안압은 우안 $17 \mathrm{mmHg}$, 좌안 $19 \mathrm{mmHg}$ 였다. 세극등현 미경검사에서 전안부는 정상이었고 안저검사에서 좌안의 망막중심오목에서 황색 반흔이 관찰되었으며(Fig. 2A) 스 펙트럼영역 빛간섭단층촬영에서 좌안 빛수용체내외절경계 부의 결손이 관찰되었다(Fig. $2 \mathrm{~B})$. 환자의 병력과 스펙트럼 영역 빛간섭단층촬영검사 결과를 바탕으로 용접광황반병 증으로 진단하고 라디칼 제거제를 처방하였다. 치료 1 년 후 좌안의 교정시력은 0.5 로 변화가 없었고, 안저검사에서 좌 안 망막중심오목의 황색 반흔과 스펙트럼영역 빛간섭단층 촬영에서 좌안 빛수용체내외절경계부의 결손은 이전과 동
일하였다(Fig. 2C, D).

\section{증례 3}

갑상선기능저하증으로 경구약을 복용 중인 48세 남자 환 자가 약 1 주일 전부터 발생한 좌안 시력저하를 주소로 내 원하였다. 환자는 내원 20 일 전부터 용접작업을 하였으며 보호장구는 간헐적으로 착용하였다. 내원 당시 환자의 최 대교정시력은 우안 1.0 , 좌안 0.9 로 측정되었고 골드만압평 안압계로 측정한 안압은 우안 $16 \mathrm{mmHg}$, 좌안 $17 \mathrm{mmHg}$ 였 으며 갑상선 안병증의 소견은 보이지 않았다. 안저검사에서 좌안 망막중심오목의 황색 반흔이 관찰되었으며(Fig. 3A) 스펙트럼영역 빛간섭단층촬영에서 고반사도의 음영이 망 막색소상피에서 외핵층에 걸쳐 관찰되었고 망막색소상피 의 손상과 빛수용체내외절경계부의 결손이 관찰되었다 (Fig. 3B). 이에 따라 용접광황반병증으로 진단하고 라디칼 제거제를 처방하고 용접작업의 중단을 권유하고 경과 관찰
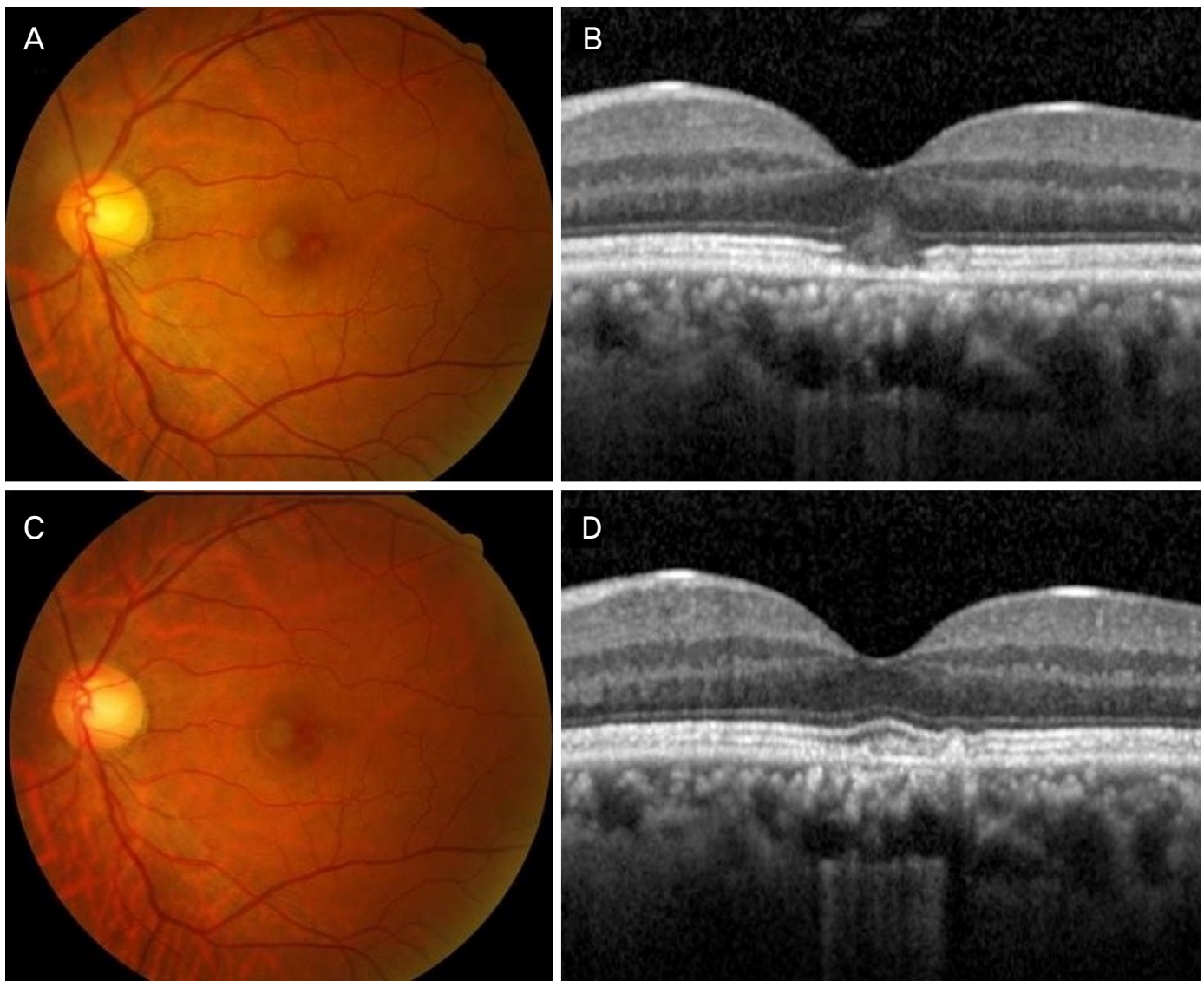

Figure 3. (Patient 3) Fundus photograph (A) and SD-OCT image (B) at the first ophthalmic examination showing yellowish retinal scar in the fovea and IS/OS junction disruption, hyperreflective band in the outer nuclear layer and RPE injury in the left eye. Fundus photograph (C) and SD-OCT image (D) after 1 years of treatment showing grater improvement in the IS/OS junction, RPE injury and retinal scar in the fovea. SD-OCT = spectral domain optical coherence tomography; IS/OS junction = photoreceptor inner segment/outer segment junction; RPE = retinal pigmented epithelium. 
하였다. 치료 1 년 후 좌안의 교정시력은 0.9 로 변화가 없었 고 안저검사에서 좌안 망막중심오목의 황색 반흔은 지속되 었으나(Fig. $3 \mathrm{C}$ ), 스펙트럼영역 빛간섭단층촬영에서 좌안 외핵층의 고반사도 음영은 소실되었고 빛수용체내외절경 계부 결손은 회복되었다(Fig. $3 \mathrm{D})$.

\section{증례 4}

고혈압으로 경구약을 복용 중인 77 세 남자 환자가 1 개월 전부터 발생한 우안의 시력저하를 주소로 내원하였다. 환 자는 1 개월 전 용접작업을 하였으며 보호장구 착용은 없었 다. 내원 당시 환자의 최대교정시력은 우안은 0.8 , 좌안은 1.0 으로 측정되었고, 골드만압평안압계로 측정한 안압은 우안 $15 \mathrm{mmHg}$, 좌안 $14 \mathrm{mmHg}$ 였다. 안저검사에서 우안 망막중심오목의 황색 반흔이 관찰되었고(Fig. 4A), 스펙트 럼영역 빛간섭단층촬영에서 우안 빛수용체내외절경계부의 결손과 망막색소상피의 손상 및 원뿔세포 외절끝층의 저반
사도 낭포 병변이 관찰되었다(Fig. 4B). 이에 용접광황반병 증으로 진단하고 경과 관찰하였다. 내원 3 주째 우안의 교정 시력은 0.7 이었으며 우안 망막중심오목의 황색 반흔은 변 화가 없었고(Fig. 4C), 스펙트럼영역 빛간섭단층촬영에서 우안 원뿔세포 외절끝층의 저반사도 낭포 병변은 소실되었 고 빛수용체내외절경계부 결손은 일부 회복되는 모습을 보 였다(Fig. 4D).

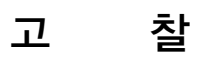

용접을 하는 동안 발생하는 자외선 및 적외선, 청색광은 눈의 구조에 손상을 입힌다. 따라서 작업장에서 눈을 보호 하기 위한 보호장구의 착용은 필수적이다. 그러나 일부 용 접공들은 불편함을 이유로 보호장구의 착용 없이 용접을 시행하는 경우가 있으며 이로 인해 눈의 손상이 발생한다. 가장 흔하게 보고된 용접에 의한 눈의 손상은 각결막염
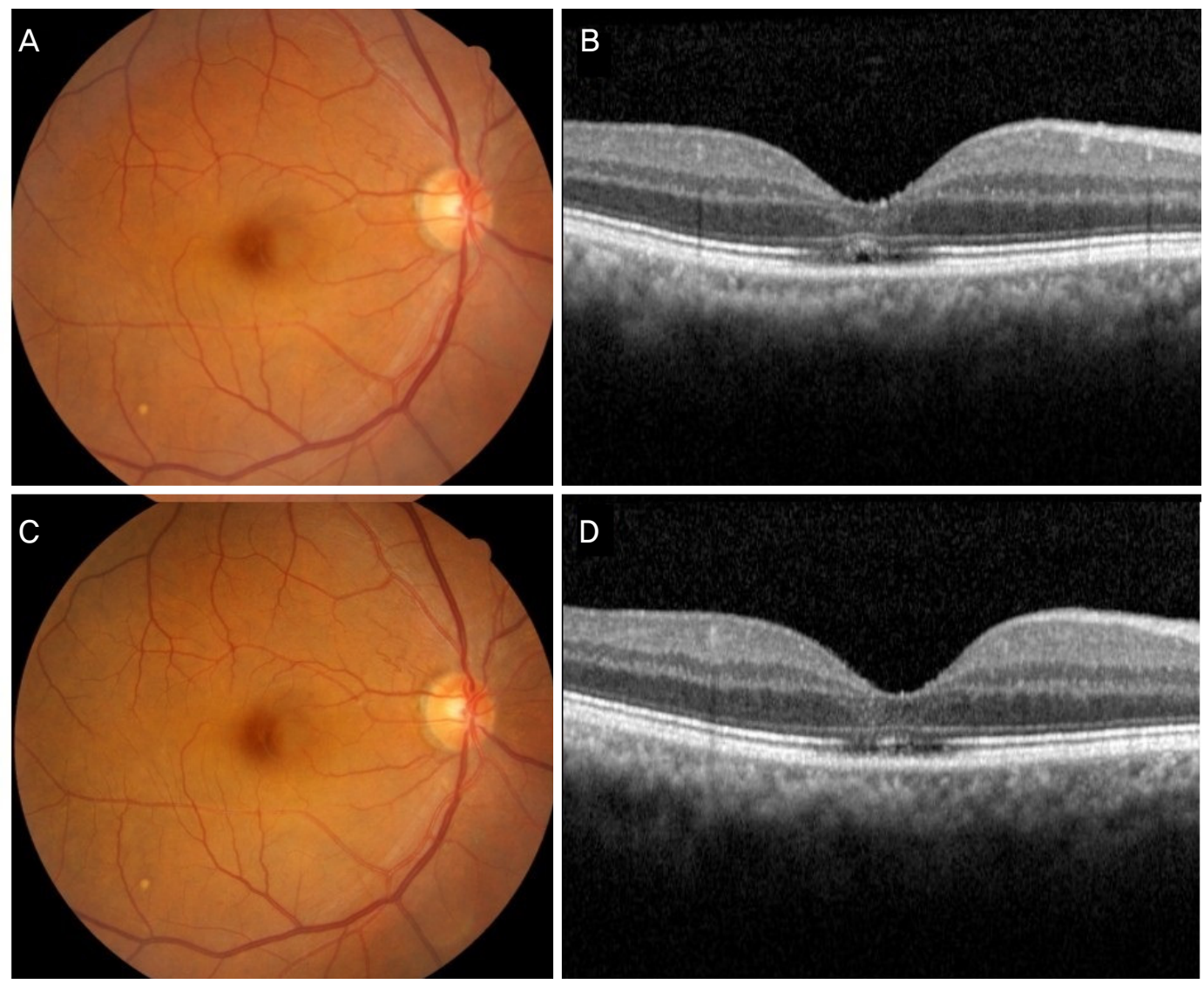

Figure 4. (Patient 4) Fundus photograph (A) and SD-OCT image (B) at the first ophthalmic examination showing yellowish retinal scar in the fovea and IS/OS junction disruption, RPE injury and hyporeflextive cystic lesion in the cone outer segment tips (interdigitation zone) in the right eye. Fundus photograph (C) and SD-OCT image (D) taken after 3 weeks, showing partially restored IS/OS junction and hyporeflextive cystic lesion with a persistent retinal scar in the fovea and RPE injury. SD-OCT = spectral domain optical coherence tomography; IS/OS junction = photoreceptor inner segment/outer segment junction; RPE = retinal pigmented epithelium. 
이다. 각막은 여러 가지 광선 중에서 원적외선, 긴 파장의 자외선과 같은 비투과성 광선에 의해 선택적으로 손상을 받게 되는데 주로 보호장구 없이 작업하거나 직접적인 작 업이 아닌 작업자 주변에서 보게 된 사람들에서 흔히 나타 난다. 용접광에 노출되면 각막상피의 조직학적 변화가 일 어나 약 5-12시간 후에 안구통증, 눈물흘림, 시야흐림 등의 증상이 나타날 수 있다. ${ }^{6}$

이러한 각결막염에서 나타나는 시야흐림 증상은 대체로 일시적인데 반해 빛에 의한 망막 손상은 영구적인 시력저 하가 발생하기도 한다. 용접광에서 발생하는 짧은 파장의 자외선과 청색광은 망막으로 흡수되어 신경감각망막 및 망 막색소상피층에 광열적 및 광화학적 손상을 야기하는데 빛 의 파장, 에너지 레벨, 노출 시간 등에 손상의 정도가 좌우 된다. ${ }^{1,2}$ 강한 빛에 의한 망막중심오목의 손상은 광화학반응 에 의해 발생하며 경도에서 중등도까지의 시력저하와 망막 중심오목의 색소성 변화로 나타난다. 이는 신경감각망막 전체에 손상이 나타나는 열화상에 의한 손상과 달리 망막 색소상피와 빛수용체에 국한되어 발생한다. ${ }^{7}$

광독성 망막병증의 유병률은 $0.14 \%$ 로 이 중 용접광에 의 한 경우는 $15 \%$ 를 차지한다. ${ }^{5,8}$ Würdemann ${ }^{9}$ 은 아크 전기용 접 중 발생되는 강한 빛에 의한 광화학 손상으로 인해 발생 한 황반원공 증례를 보고하였고, Yang et $\mathrm{al}^{10}$ 은 40 명의 용 접공 중 11 명(23.8\%)에서 망막색소상피의 변화와 빛수용체 내외절경계부의 결손을 동반한 용접광황반병증을 진단하 였는데 이 중 8 명은 양안, 3 명은 단안에 발생하였다고 보고
하였다. 최근에는 기존의 시간영역 빛간섭단층촬영보다 해 상력이 좋고 측정 시간이 짧아서 망막 안층과 망막 바깥층 을 정교하게 구분하여 정량적 측정이 가능한 고해상도 스 펙트럼영역 빛간섭단층촬영을 이용하여 진단하고 경과 관 찰한 증례들이 보고되었다. Park et $\mathrm{al}^{11}$ 은 1 명의 증례에서 스펙트럼영역 빛간섭단층촬영으로 관찰한 다양한 양상의 망막 손상을 보고하였는데 본 연구의 증례 1,3 에서 보인 외핵층에서 빛수용체내외절경계부에 이르는 고반사도 병 변과 증례 4 와 같은 외핵층에서 관찰된 낭포성 변화와 더 불어 망막색소상피의 불규칙한 손상 또는 망막색소상피의 비대가 나타났다고 보고하였다. Zhang et $\mathrm{al}^{12}$ 은 용접광황 반병증을 진단받은 11 명의 환자를 분석하여 내원 당시 최 대교정시력과 스펙트럼영역 빛간섭단층촬영에서 빛수용체 내외절경계부의 결손 길이, 원뿔세포 외절끝층의 결손 길 이가 추후 시력을 예측하는 데 유용하다고 보고하였다. 본 연구에서도 회복을 보인 증례 $1,3,4$ 의 경우 초기 내원 당 시의 시력이 증례 2와 비교하여 좋았음을 알 수 있다(Table 1).

대부분의 용접광황반병증은 대체로 시간이 지나면 자연 적으로 회복된다고 보고되었지만 일부에서는 영구적인 시 력장애 및 망막장애를 동반하기도 한다. ${ }^{13}$ 빛에 의한 망막 병증은 치료 없이 경과 관찰하는 것이 대부분이나 스테로 이드 제제 및 항산화제를 사용하였을 때 망막 손상에 대한 세포면역 반응을 감소시켜 망막회복에 도움이 된다는 보고 가 있다. 하지만 연구에 따라 시력예후의 결과가 다양하게 나타나 명확한 치료법으로 규명되지는 않았다. ${ }^{14,15}$

Table 1. Clinical characteristics and ophthalmologic finding

\begin{tabular}{|c|c|c|c|c|c|c|c|c|c|c|}
\hline No. & $\begin{array}{c}\text { Age } \\
\text { (years) }\end{array}$ & Sex & $\begin{array}{c}\text { Involved } \\
\text { eye }\end{array}$ & $\begin{array}{l}\text { Initial } \\
\text { BCVA } \\
\text { OD/OS }\end{array}$ & $\begin{array}{l}\text { Final } \\
\text { BCVA } \\
\text { OD/OS } \\
\end{array}$ & $\begin{array}{c}\text { Duration } \\
\text { of welding } \\
\text { work } \\
\end{array}$ & $\begin{array}{l}\text { From } \\
\text { symptom } \\
\text { to visit } \\
\end{array}$ & $\begin{array}{l}\text { Follow-up } \\
\text { duration }\end{array}$ & $\begin{array}{l}\text { Fundus } \\
\text { photo }\end{array}$ & SD-OCT \\
\hline$\overline{1}$ & 39 & $\mathrm{M}$ & $\mathrm{OS}$ & $1.0 / 0.8$ & $1.0 / 1.0$ & 2 months & 2 weeks & 1 year & $\begin{array}{l}\text { Yellowish } \\
\text { retinal scar }\end{array}$ & $\begin{array}{l}\text { IS/OS junction disruption } \\
\text { RPE injury } \\
\text { Hyperreflextive band in } \\
\text { the outer nuclear layer }\end{array}$ \\
\hline 2 & 32 & M & OS & $1.0 / 0.5$ & $1.0 / 0.5$ & 7 months & 6 months & 1 year & $\begin{array}{l}\text { Yellowish } \\
\text { retinal scar }\end{array}$ & IS/OS line disrupture \\
\hline 3 & 48 & M & OS & $1.0 / 0.9$ & $1.0 / 0.5$ & 3 weeks & 1 week & 3 months & $\begin{array}{l}\text { Yellowish } \\
\text { retinal scar }\end{array}$ & $\begin{array}{l}\text { IS/OS junction disruption } \\
\text { RPE injury } \\
\text { Hyperreflextive band in } \\
\text { the outer nuclear layer }\end{array}$ \\
\hline 4 & 77 & M & OD & $0.8 / 1.0$ & $0.7 / 1.0$ & 1 month & 2 weeks & 3 weeks & $\begin{array}{l}\text { Yellowish } \\
\text { retinal scar }\end{array}$ & $\begin{array}{l}\text { IS/OS junction disruption } \\
\text { RPE injury } \\
\text { Hyporeflextive cystic } \\
\text { lesion in the cone outer } \\
\text { segment tips } \\
\text { (interdigitation zone) }\end{array}$ \\
\hline
\end{tabular}

BCVA = best corrected visual acuity; OD/OS = oculus dexter/oculus sinister; SD-OCT = spectral domain-optical coherence tomography; $\mathrm{M}=$ male; IS/OS junction = photoreceptor inner segment/outer segment junction; RPE = retinal pigmented epithelium. 
본 증례에서 용접광황반병증으로 진단된 환자는 4 명 모두 단안에 발생하였고 이들 중 3 명에게는 경구 스테로이드 제 제 또는 항산화제를 복용하였고 1명(증례 4)은 경과 관찰하 였다. 모든 환자는 스펙트럼영역 빛간섭단층촬영기 Spectralis $\mathrm{OCT}^{\mathrm{TM}}$ (Heidelberg Engineering, Heidelberg, Germany)를 이용하여 망막중심오목의 변화를 연속적으로 살펴보았다.

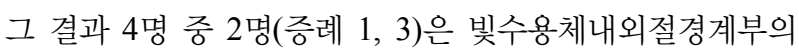
결손이 회복되었고 1 명(증례 4)은 부분적인 회복을 보였으 며 다른 1명(증례 2)의 경우 변화 없이 지속되었다. 회복되 는 소견을 보인 2 명(증례 1,3$)$ 은 용접을 시행한 시간과 증 상 발생 후 병원을 내원한 기간이 짧았고, 스펙트럼영역 빛 간섭단층촬영검사에서 망막색소상피에서부터 외핵층에 걸 쳐 고반사도의 병변이 관찰되는데 이는 질환의 초기에 나 타나는 소견으로 추측되며 향후 빛수용체내외절경계부의 회복과 좋은 시력 예후와 연관이 있을 것으로 생각된다. 이 에 반해 증례 2 는 용접광에 의한 피폭시간이 길고 증상 발 생 이후부터 병원 내원까지의 기간이 길었으며 빛수용체내 외절경계부에만 손상이 관찰되었다(Table 1). 이는 외핵층 에서 망막색소상피까지 이르는 영역에 손상이 있었던 다른 증례들과는 다르게 회복이 되지 않고 영구 결손으로 남을 가능성이 커 시력 및 해부학적으로 예후가 나쁠 것으로 생 각된다.

본 증례들에서와 같이 용접광황반병증은 용접광의 피폭 시간, 증상 발생 후 치료를 시작하기까지 걸린 시간, 초기 내원 당시의 시력, 스펙트럼영역 빛간섭단층촬영에서 외망 막층의 손상 양상에 따라 예후가 달라질 수 있음을 추측해 볼 수 있다. 이를 확인하기 위해 더 많은 환자를 대상으로 한 추가적인 연구가 필요할 것으로 생각된다. 또한 용접작 업 환경에서 발생할 수 있는 용접광황반병증을 예방할 수 있도록 노출 시간을 최소화하고 보호장구 착용의 중요성 및 빛에 의한 망막 손상으로 인한 영구적인 시력저하 위험 성에 대한 충분한 교육이 필요하리라 생각된다.

요약하면, 저자들은 보호장구의 착용 없이 용접작업을 한 후 발생한 용접광황반병증을 경구 스테로이드제제와 항 산화제로 치료하며 질환의 초기부터 스펙트럼영역 빛간섭 단층촬영으로 경과 관찰을 한 4 명의 증례를 경험하였기에
보고하는 바이다.

\section{REFERENCES}

1) Kim YJ, Chung IY, Kim SJ, et al. A case of maculopathy from handheld green laser pointer. J Korean Ophthalmol Soc 2015;56: 447-51.

2) Choi SW, Chun KI, Lee SJ, Rah SH. A case of photic retinal injury associated with exposure to plasma arc welding. Korean $\mathrm{J}$ Ophthalmol 2006;20:250-3.

3) Karp KO, Flood TP, Wilder AL, Epstein RJ. Photic maculopathy after pterygium excision. Am J Ophthalmol 1999;128:248-50.

4) Ruiz-del-Río N, Moriche-Carretero M, Ortega-Canales I, et al. Photic maculopathy and iris damage in a psychotic patient. Arch Soc Esp Oftalmol 2006;81:165-8.

5) Maier R, Heilig P, Winker R, et al. Welder's maculopathy? Int Arch Occup Environ Health 2005;78:681-5.

6) Kim YK, Lee HK, Lee JH. An experimental study of the corneal epithelial damage by electric welding light on the rabbit cornea. J Korean Ophthalmol Soc 1988;29:61-7.

7) Stefaniotou M, Katsanos A, Kaloudis A, et al. Spectral-domain optical coherence tomography in lightening-induced maculopathy. Ophthalmic Surg Lasers Imaging 2012;43:E35-7.

8) Stokkermans TJ, Dunbar MT. Solar retinopathy in a hospital based primary care clinic. J Am Optom Assoc 1998;69:625-36.

9) Würdemann HV. The formation of a hole in the macular: light burn from exposure to electric welding. Am J Ophthalmol 1936;19:457-60.

10) Yang $X$, Shao D, Ding $X$, et al. Chronic phototoxic maculopathy caused by welding arc in occupational welders. Can J Ophthalmol 2012;47:45-50.

11) Park DW, Alonzo B, Faridi A, Bhavsar KV. Multimodal imaging of phototic maculopathy from arc welding. Retin Cases Brief Rep 2018 Sep 26 doi: 10.1097/ICB.000000000000823. [Epub ahead of print]

12) Zhang C, Dang G, Zhao T, et al. Predictive value of spectral-domain optical coherence tomography features in assessment of visual prognosis in eyes with acute welding arc maculopathy. Int Ophthalmol 2019;39:1081-8.

13) Magnavita N. Photoretinitis: an underestimated occupational injury? Occup Med (Lond) 2002;52:223-5.

14) Hirsch DR, Booth DG, Schocket S, Sliney DH. Recovery from pulsed-dye laser retinal injury. Arch Ophthalmol 1992;110:1688-9.

15) Zwick H, Stuck BE, Dunlap W, et al. Accidental bilateral Q-switched neodymium laser exposure: treatment and recovery of visual function. In BiOS'98 International Biomedical Optics Symposium. International Society for Optics and Photonics 1998;3254:80-9. 


\section{= 국문초록 $=$}

\section{스펙트럼영역 빛간섭단층촬영으로 경과 관찰한 용접광황반병증}

목적: 용접 작업 후 발생한 용접광황반병증 증례들의 경과 과정을 스펙트럼영역 빛간섭 단층촬영기기를 통해 관찰하고 경험하였기에 이를 보고하고자 한다.

증례요약: 보호장구의 착용 없이 용접작업을 시행한 후 발생한 시력저하를 주소로 4명(4안)의 환자가 내원하였다. 환자들의 평균 시력 은 0.6 이었고 안저검사상 망막중심오목에 황색의 반흔이 관찰되었으며, 스펙트럼영역 빛간섭단층촬영에서 빛수용체내외절경계부가 소실되었고 망막색소상피의 손상이 관찰되었다. 이에 용접광황반병증으로 진단하고 이 중 3 명에게는 경구 스테로이드제제 또는 항산 화제를 처방하였다. 이들 4 명 중 용접광에 의한 피폭시간이 짧았던 2 명은 스펙트럼영역 빛간섭단층촬영에서 빛수용체내외절 경계부 의 손상이 회복되었고 피폭시간이 길었던 2 명 중 1 명은 부분적인 회복 소견을 보였지만, 다른 1 명은 빛수용체내외절경계부 소실은 변화 없이 지속되었다.

결론: 용접작업을 시행한 4명의 환자에서 용접광황반병증을 진단하고 경구 스테로이드제제, 항산화제 병합 치료를 하며 스펙트럼영역 빛간섭단층촬영으로 질환의 초기부터의 진행양상을 경험하였기에 이를 보고하고자 한다.

〈대한안과학회지 2019;60(12):1344-1351〉

김지혜 / Ji Hye Kim

창원경상대학교병원 안과

Department of Ophthalmology,

Gyeongsang National University

Changwon Hospital

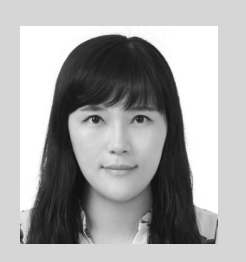

